\title{
The Change of Surface Properties of Mixed Pigments at Grinding
}

\author{
Norimichi Kawashima* and Knjiro Meguro* \\ Department of Applied Chemistry, \\ Faculty of Science, \\ Science University of Tokyo*
}

\begin{abstract}
The mixture of inorganic pigments and organic pigments in several weight ratios was ground by a grinder. The changes of the surface properties of the pigment mixtures with grinding time were investigated by specific surface area measurement, $\mathrm{X}$ ray diffraction analysis and electronmicrograph.

As a conclusion, when the amount of organic pigment was large in proportion to that of the inorganic one, the inorganic pigment was covered by organic one and the grinding of the inorganic pigment was interfered by the lubricating action of the organic one. On the other hand, when the amount of inorganic pigment was large in proportion to the organic one, the lubricating action of the organic pigment was not found.
\end{abstract}

*1-3, , Kagurazaka, Shinjiku-ku, Tokyo 


\title{
二種顔料の混合摩砕による表面物性の変化
}

\author{
川島 德 道・目黒謙次郎*
}

\begin{abstract}
要
旨

本研究に打いては, 有機顔料と無機顔料を様々な混合比（以下すべて重量比である） で混合し, 摩砤時間による混合粉体の表面物性の変化を, 比表面積, X線回折括よび電子 顕微鏡を用いて研究した。その結果, 2 種顔料の混合摩砕に際して, 混合顔料中の有機顔 料の混合比が大きい場合には, 無機顔料の表面は有機顔料で覆われ, 有機顔料の潤滑作用 のために，無機顔料の摩砕が妨げられる事が分かった。ところが，有機顔料の混合比が極 端に少なくなった場合には, 有機顔料は, 混合摩砕の際に潤滑效果を示さない事が分かっ た。
\end{abstract}

\section{1. 緒 言}

顔料工業界に怙いて，中間色を得るために，二種また はそれ以上の顔料を混合する事は良く行なわれている事 であるが，その際，混合過程に特いて，さまざまな表面物 性を持ったものが形成されると考えられる。それは顔料 の色分かれ，色浮き等と関連して，単一顔料を用いた場 合とは異なる重要な問題を含んでいる1,2)。ところが, 単一顔料 ${ }^{3,4}$ や無機一無機顔料 ${ }^{5}$ とついての研究は数多く 行なわれているが，無機一有機顔料の混合系についての 研究は殆んど行なわれていない。そこで筆者らは，その 点に注目して，(前報に拈いて ${ }^{6)} \alpha$-銅フタロシアニンと チタニア㧤よび $\gamma$-キナクリドンとチタニアの $1: 1$ (重 量比）の混合系について, 混合摩砕により, 表面物性が 如何に变化するかを研究した。その結果, 混合摩砕が進 むにつれ，無機顔料の回りを有機顔料が覆ってゆくとい う事実が, 浸セキ熱, 電子顕微鏡およびX線回折等の測 定により得られた。本実験に和いては， $\alpha$-銅フタロシア ニンとアルミナを選び, 更に有機一無機顔料の混合の比 率を変えていった場合に，混合過程に特いて，どのよう な変化が生ずるかといらことを研究した。

\section{2. 実験}

\section{1 試料}

使用した顔料は，次の二種類である。無機顔料として

昭和 48.9.25 受理

* 東京理科大学理学部

東京都新宿区神楽坂 $1-3$
はアルミナ, 有機顔料は $\alpha$-銅フタロシアニン（以下 $\alpha-$ $\mathrm{CuPc}$ と略記する) である。アルミナは, 国産化学(株) 製の市販のクロマトグラフ用アルミナ（以下Aと略記す る）をそのまま用いた。有機顔料は大日本インキ(株)の 研究室より供給された表面未処理の高純度 $\alpha-\mathrm{CuPc}$ をそ のまま使用した。

\subsection{1 摩砕処理}

試料の摩砕は石川式メノウ製カキマゼライカイ機を用 い, メノウ乳鉢の大きさは, 内径 $12 \mathrm{~cm}$, 深さ $3 \mathrm{~cm}$ で ある。 $\alpha-\mathrm{CuPc}$ とAの混合重量比は $1: 3,1: 15,1$ : 39 物よび $1: 79$ とし, 一回に全量 $8 \mathrm{~g}$ として 10 分, 30 分, 60 分, 180 分, 混合摩砕を行なった。摩砕の雾囲気 は, 室温, 空気中で行なった。

\section{2 比表面積の測定}

通常の BET 理論に基づき, 液体窒素温度に抢ける $\mathrm{N}_{2}$ ガスの吸着等温線の測定から, BET プロットを適用し, 窒素分子断面積を $16.2 \AA$ として, 比表面積を求めた。 死容積の測定にはへリウムガスを用いた。測定に先だ ち, 試料は $10^{-5}$ Torr で 1 時間脱気を行なった。な和ア ルミナ単独のみは, $100^{\circ} \mathrm{C}$ で脱気し他の試料は, 有機顔 料が熱により分解することを避けるために室温で脱気を 行なった。

\section{$2.3 \mathrm{X}$ 線回折}

摩研による結晶構造の変化を調べるために, X線回折 を行なった。使用したX線回折装置は, 日本電子製ガイガ

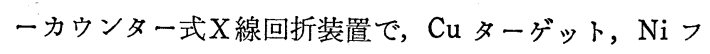
ィルターによる $\mathrm{CuK}_{\alpha}$ 線を用いた。測定条件は, 走查速 度 $1 / 2^{\circ} 2 \theta / \mathrm{min}$ 時定数 2 で行ない, 管電圧; $30 \mathrm{kV}$, 管 
電流； $20 \mathrm{~mA}$ とした。

\section{4 電子顕微鏡}

摩砕により顔料粒子が, どのように変化するかを直接 観察するため, 電子顕微鏡写真の撮影を行なった。装置 は日立 HU-11 型電子顕微鏡を用い, 試料はコロジオン 膜へのふりかけ法により作成した。

\section{3. 結果及び考察}

\section{$3.1 \mathrm{~A}$ 及び $\alpha-\mathrm{CuPc}$ 単独について}

$\mathrm{A}$ 打よび $\alpha-\mathrm{CuPc}$ 単独の摩砕時間による比表面積変 化を図ー1 に表わした。図より明らかなように，A単独

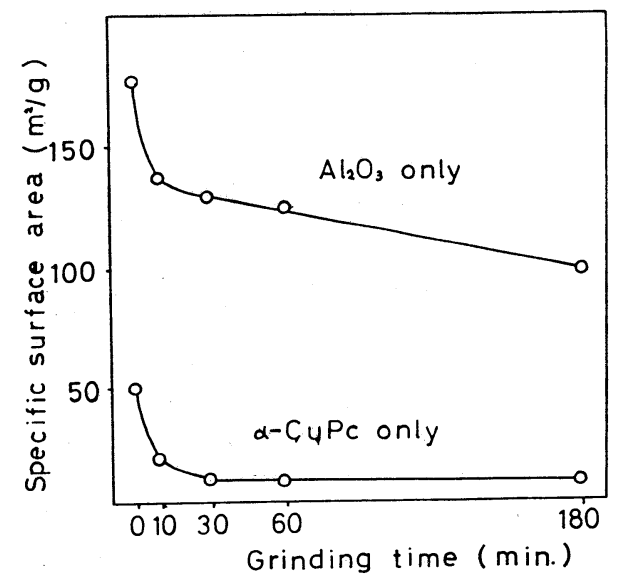

Fig. 1. Change of the specific surface areas of $\alpha-\mathrm{CuPc}$ and alumina with grinding

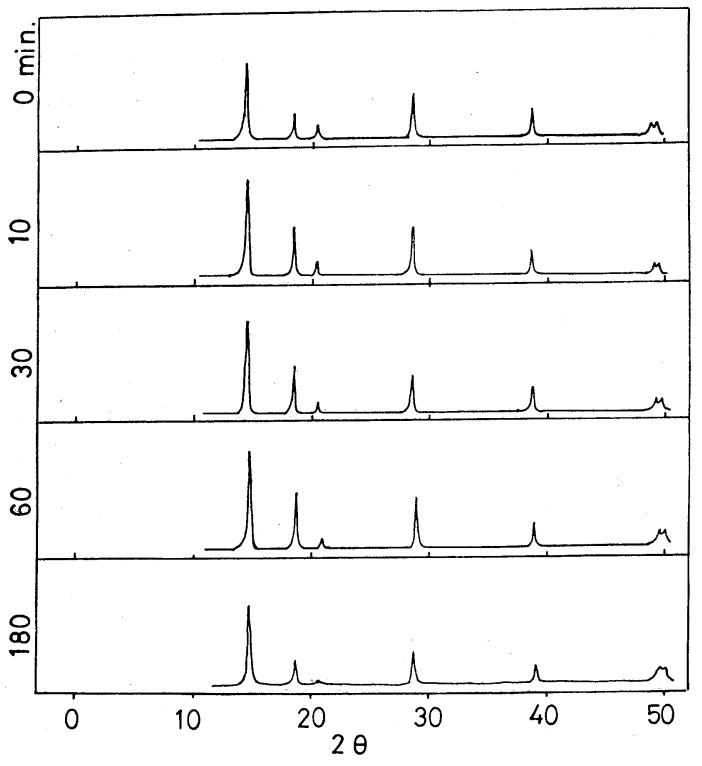

Fig. 2. X-ray diffraction patterns of alumina at different grinding time

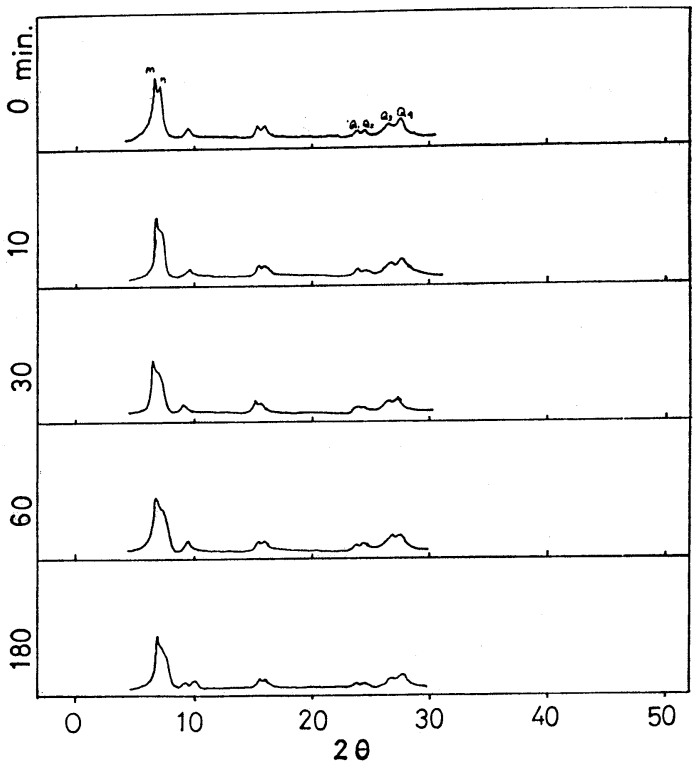

Fig. 3. X-ray diffraction patterns of $\alpha$-CuPc at different grinding time

狺よび $\alpha-\mathrm{CuPc}$ 単独共に, 摩砕の進行に伴って, 比表 面積は減少する傾向にあることが分かる。通常, 粉体を 摩砕した場合, 粒子は微細化され, 比表面積が増加する というのが，一般的な傾向であるが，このように摩砕に より比表面積が減少するものや, また単純な増加・減少 曲線を示さないものも知られている7)。これは, 後述の 電子顕微鏡写真からも明らかなように, 粉体が摩砕によ る熱エネルギーを吸収し，粒子は相互に凝集して二次粒 子を形成するために比表面積が減少するものと思われ る。

$A$ 単独について摩砕に伴う結晶構造の変化を表わす $\mathrm{X}$ 線回折の結果を図-2 に示した。摩砕が進むにつれ $2 \theta=$ $21^{\circ}$ 付近のピークが他のピークと比べ著しく減少してゆ くことが分かる。同様に図-3 は $\alpha-\mathrm{CuPc}$ 単独の粉砕時 間によるX線回折の結果であるが， $\alpha-\mathrm{CuPc}$ の特徵的な (200) 面拈よび (002) 面に対応する $2 \theta=5 \sim 8^{\circ}$ 付近のピ 一ク和よび $2 \theta=25^{\circ}$ 付近の 4 つの連続したピークが摩砕 の進行と共に, 順次くずれ，また，低角度側の $2 \theta=5$ $8^{\circ}$ 付近の 2 本のピークは 180 分摩砕の後は 1 本のブロー ドなピークになってゆくことがわかる。

図-4 扣よび図-5 の未摩砕のものと 180 分摩砕したものの電子顕微鏡写真 の結果であるが, これょり粒子は, 微細化され相互に凝 集している様子がはっきりわかる。

$$
\alpha-\mathrm{CuPc}+\mathrm{A}(1: 3) \text { の混合摩砕 }
$$



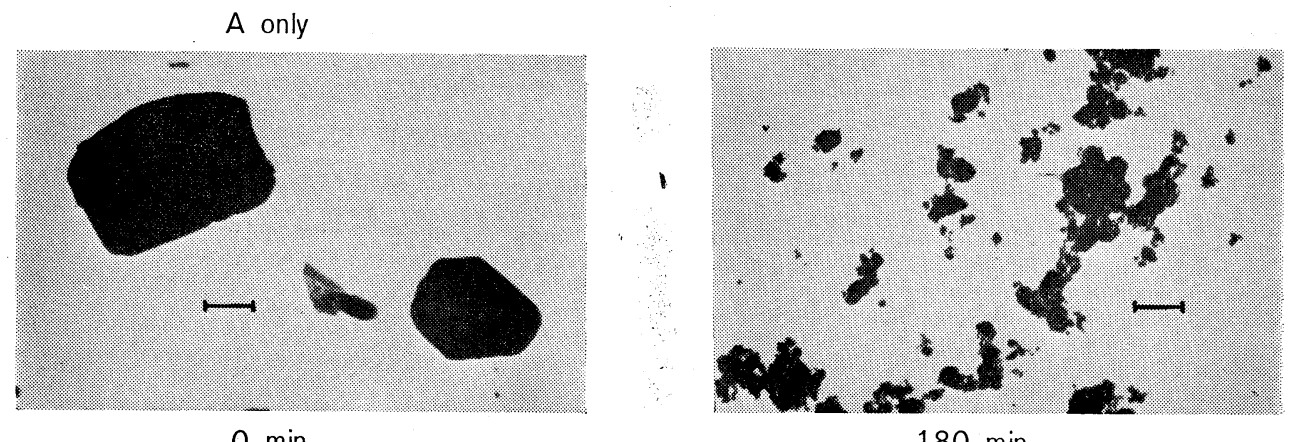

Fig. 4. Electronmicrograph of original and ground pigment. The linear dimension on electronmicrograph represents one micron

CuPc only
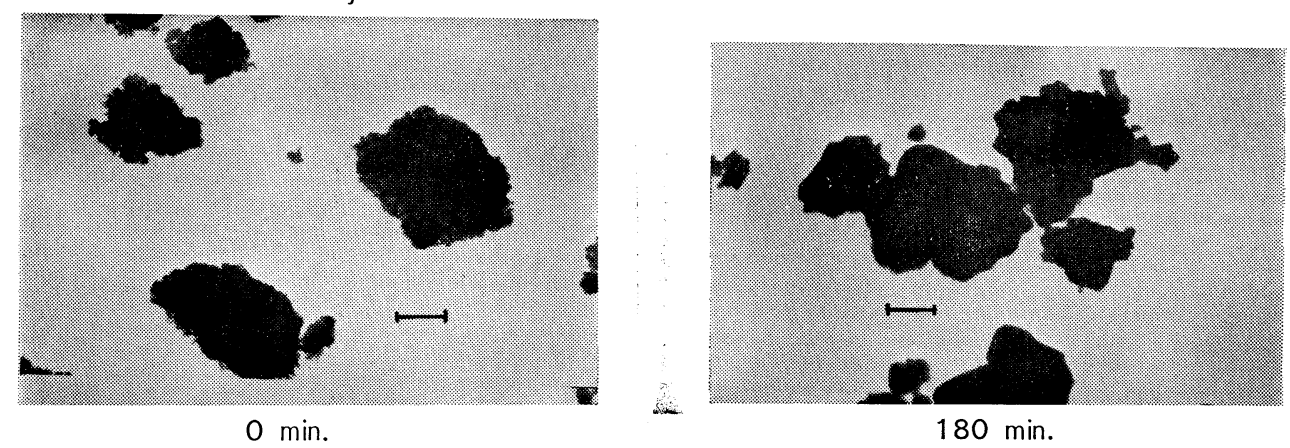

Fig. 5. Electronmicrograph of original and ground pigment. The linear dimension on electronmicrograph represents one micron Length

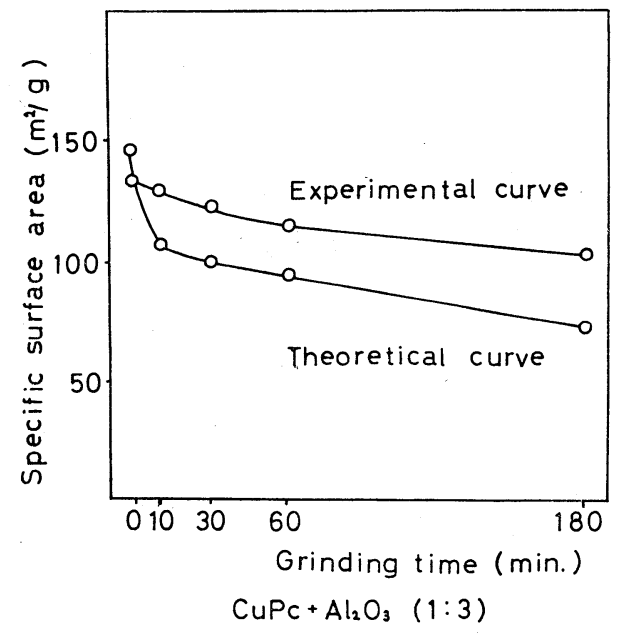

Fig. 6. Change of the specific surface areas of mixed pigment $(1: 3)$ with grinding

図-6 は $\alpha$-CuPc とAの混合比 $1: 3$ の混合顔料の摩砕 による比表面積変化であるが, これる A およよび $\alpha-\mathrm{CuPc}$ 単一顔料の場合と同様, 比表面積は, 摩砕時間の增加と ともに,減少してゆくことがわかる。な詾四中の theore- tical curve（理論曲線）というのは, 比表面積に加成 性が成り立つものと仮定して, 四-1 に表わした A 単独 扣よび $\alpha-\mathrm{CuPc}$ 単独の比表面積の值から算出した值を 摩砕時間に対してプロットしたものであり, 摩砕時間 0 分を除いて, 実湘值は理論值よりも大きくなっているこ とがわかる。もし摩砕が進む注ど, 粒子は微細化され, 凝集して比表面積が減少するものとすれば, 実測值が理 論值よりも大きいといら事は, 無機顔料にフタロシアニ ンが入ったことにより無機顔料の摩砕が抑兄られ, 粒子 が凝集しにくくなっていることを示するのである。すな わち混合顔料中の $\alpha$-CuPc が潤滑剤の働きをしAの摩 砕を妨げているるのと考兄られる。逆に理論值が実測值 より大きくなる時は, 混合顔料中の $\alpha-\mathrm{CuPc}$ が潤滑効 果を示さず，したがってAの摩䂶が妨げられることはな いと考えられる。な怙このことはX線回折の結果敊よび 電子顕微鏡写真にもよく表われている。

図-7 は (1:3) 混合顔料の摩砝によるX線回折図であ るが， $\alpha$-CuPc の (200) 面誩よび (002) 面に対応する $2 \theta=5 \sim 8^{\circ}$ 付近のピークと $2 \theta=25^{\circ}$ 付近の 4 つの連続し たピークが摩砕の進行に伴いそれぞれブロードとなり， 
結晶形がくずれるだけで，A単独の場合にくずれた， $2 \theta=21^{\circ}$ 付近のピークは単独の摩砕に比べそれほど変化 してないことが分かる。すなわち $\alpha-\mathrm{CuPc}$ が摩确され る割にAはそれほど摩研されていないことが明らかであ る。図-8は (1:3) 混合顔料の未摩砕のものと 180 分 摩砕の電子顕微鏡写真の結果である。Aの粒子は $\mathrm{A}$ 単独 の場合よりも摩砕されていないかわりに， $\alpha-\mathrm{CuPc}$ が単 独の摩研よりも微細化されてAの粒子の回りに付着して いる様子が分かる。X線回折括よび電子顕微鏡の結果よ り $\alpha-\mathrm{CuPc}$ の潤滑作用のためAの摩砕が物さえられて いることが明らかである。

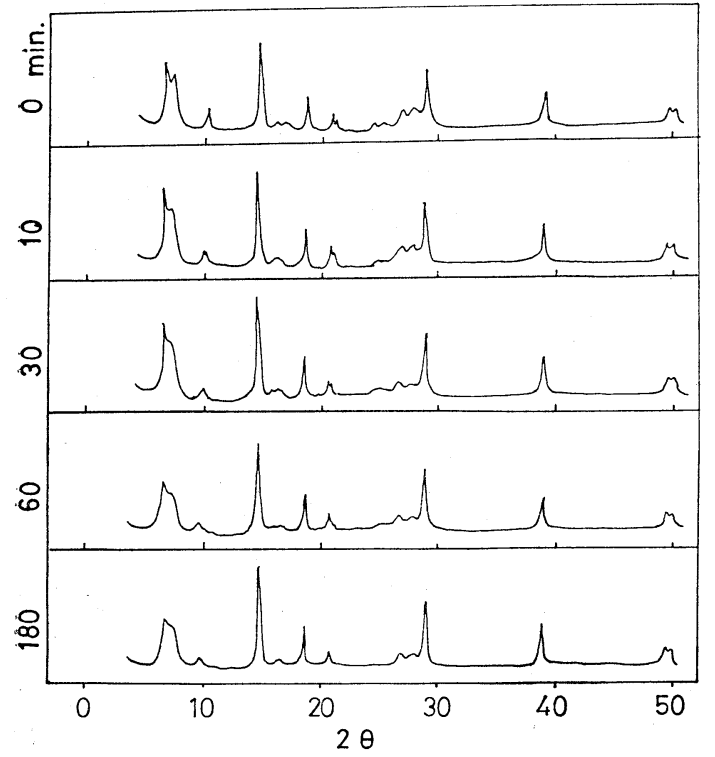

Fig. 7. X-ray diffraction patterns of mixed pigment $(1: 3)$ at different grinding time
$\alpha-\mathrm{CuPc}+\mathrm{A}$ の $1: 15$ 混合摩砕

図-9 は $\alpha$-CuPc をAの混合比 $1: 15$ の場合の摩砕時間 による比表面積変化であるが, $1: 3$ と同様, 摩砕時間の 増加につれ，比表面積は減少し，また摩砕時間 0 分を除 いて，実験值が理論值よりも上になっている。すなわち この混合比の場合にも $\alpha-\mathrm{CuPc}$ の潤滑効果が表われる ことが予想される。図-10 は粉砕時間によるX線回折 の変化を表わしてある。この混合比の場合には $\alpha-\mathrm{CuPc}$ の特徵的な $2 \theta=25^{\circ}$ 付近の連続した 4 本のピークはも はや見られないが，（200）面 (002) 面に対応する $2 \theta=$ 5〜8 付近のピークがくずれただけで, 単体のAでくずれ た $2 \theta=21^{\circ}$ 付近のピークはそれほど減少していないこと がわかる。図-11 は同混合顔料の未粉砕と 180 分摩砕後

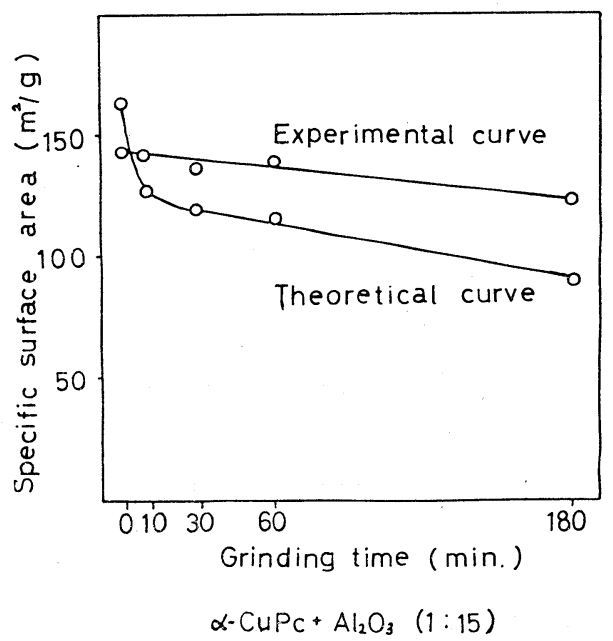

Fig. 9. Change of the specific surface areas of mixed pigment $(1: 15)$ with grinding
A

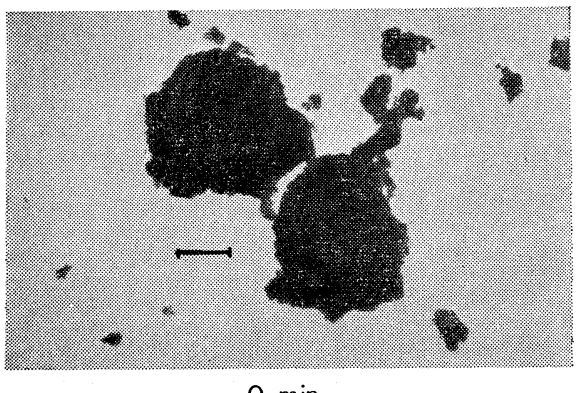

$0 \mathrm{~min}$.
B

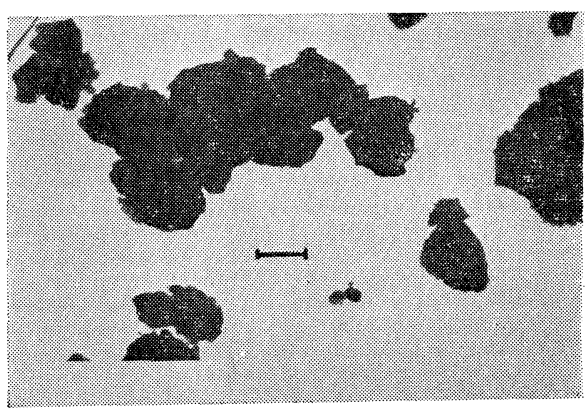

$180 \mathrm{~min}$.

Fig. 8. Electronmicrographs of $(1: 3)$ mixed pigment. The linear dimension on electronmicrograph represents on micron length
A. $\alpha-\mathrm{CuPc}+\mathrm{Al}_{2} \mathrm{O}_{3}(1: 3)$ original
B. $\alpha-\mathrm{CuPc}+\mathrm{Al}_{2} \mathrm{O}_{3}(1: 3)$ ground for $180 \mathrm{~min}$ 
の電子顕微鏡写真の結果であるが，これも $1: 3$ 混合摩 确の場合之同様，Aは単独のものに比へてそそれ注ぞ摩砕 されず, $\alpha-\mathrm{CuPc}$ の摩砕された微粒子が Aの回りに付着 している。したがって (1:15) 混合顔料も $1: 3$ の場合 と同様 $\alpha$-CuPc の潤滑作用が摩砝過程に招いてはっき りと認められる。

$$
\alpha-\mathrm{CuPc}+\mathrm{A} \text { の } 1: 39 \text {. 混合摩研 }
$$

$\alpha-\mathrm{CuPc}$ が混合摩砕の際に潤滑効果をどのくらいの混合 比をで示すかを調べるため, 更に $\alpha-\mathrm{CuPc}$ の混合顔料 中の比率を減らしたのが次の $\alpha-\mathrm{CuPc}$ と Aの混合比 1 ： 39 の結果である。図-12 は, 1:39 混合顔料の摩砕に

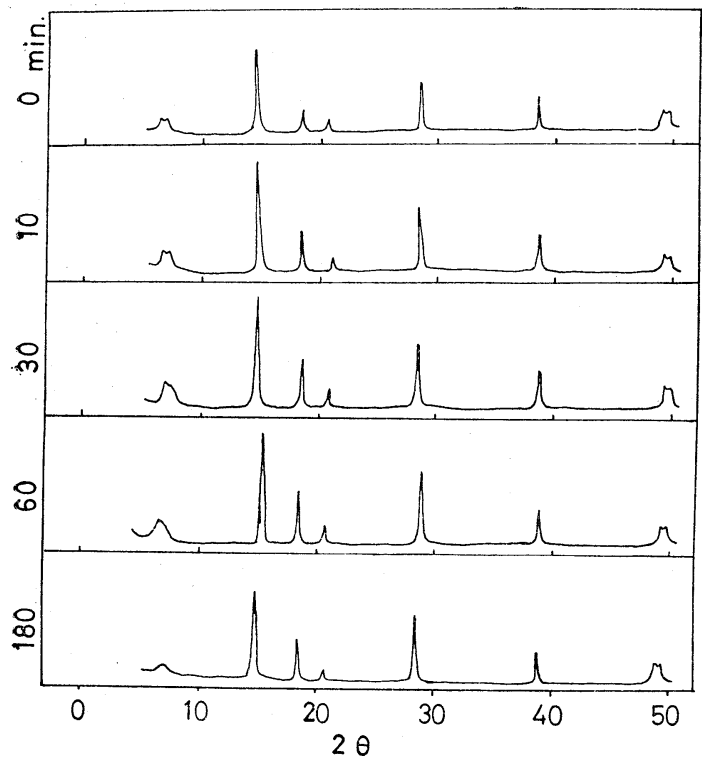

Fig. 10. $X$-ray diffraction patterns of mixed pigment (1:15) atdifferent grinding time
よる比表面積変化である。摩砕時間の増加従って 1 ： 3, 1:15 の場合と同様, 此表面積は減少している。乙 かし $1: 39$ の場合は今までとは逆に実験値が理論值より る小さくなっていることがわかる。すなおらこのことは 前述のように $\alpha-\mathrm{CuPc}$ が混合摩碎の際に潤滑効果を表 わしていないことを示している。図-13 は摩砕時間によ るX線回折の変化を示したものである。この場合には, $\alpha-\mathrm{CuPc}$ の特徴的な $2 \theta=5 \sim 8^{\circ}$ 付近のピークも 180 分の 摩砕後には, 注之んど消失し, 昰た $2 \theta=21^{\circ}$ 付近の Aの ピークも 180 分の摩砕後には, 汪とんど消失しているこ とが明らかである。図-14 1 1：39 混合顔料の未摩砕拉 よび 180 分摩砕後の電子顕微鏡写真の結果でる。1 180 分 摩砕の後には，Aの粒子も単独摩砝の場合と同様かなり 細かくなって粒子が相互に凝集していることがわかっ



Fig. 12. Change of the specific surface areas of mixed pigment ( $1: 39)$ with grinding
A

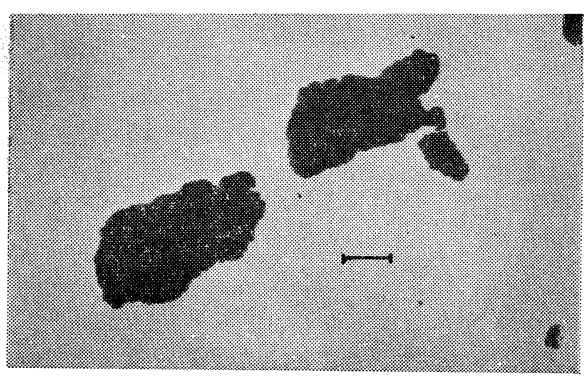

0 min.
$\alpha-\mathrm{CuPc}_{\mathrm{C}}+\mathrm{Al}_{2} \mathrm{O}_{3}(1: 15)$

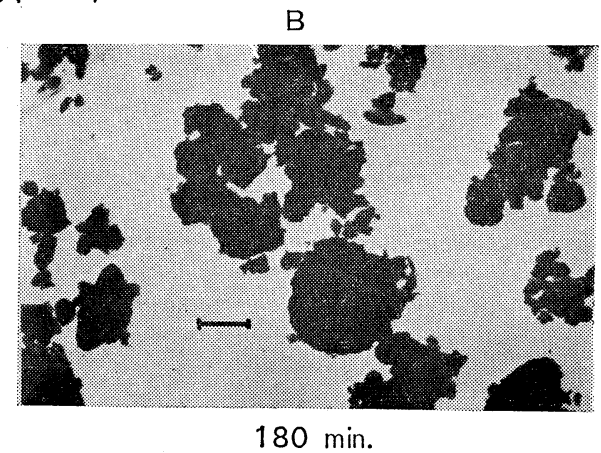

Fig. 11. Electronmicrographs of $(1: 15)$ mixed pigments $(\alpha-\mathrm{CuPc}+\mathrm{A})$. The linear dimension on electronmicrograph represents one micron length
A. original
B. ground for $180 \mathrm{~min}$ 
た。以上のことより $1: 39$ の混合摩挽の場合には， $\alpha-$ $\mathrm{CuPc}$ の潤滑作用は認られなかった。

$$
\alpha-\mathrm{CuPc}+\mathrm{A}(1: 79) \text { の混合摩研 }
$$

更に極端に混合顔料中の $\alpha-\mathrm{CuPc}$ の含有量を減らし た場合には次のよらな結果が得られた。図-15 は, 混合 比 $1: 79$ の混合顔料の摩砕による比表面積变化を示した ものである。比表面積は今までと同様, 摩砕時間の増加 とともに減少してゆく傾向にある。また, 混合比 $1: 39$ の場合と同様，実験值は理論值よりも下になっている。 すなわちこの場合にも $\alpha-\mathrm{CuPc}$ の潤滑作用は認められ ないものと思われる。図-16 は摩砕時間によるX線回折 の変化を示した結果であるが, 混合比に 1：79の場合も

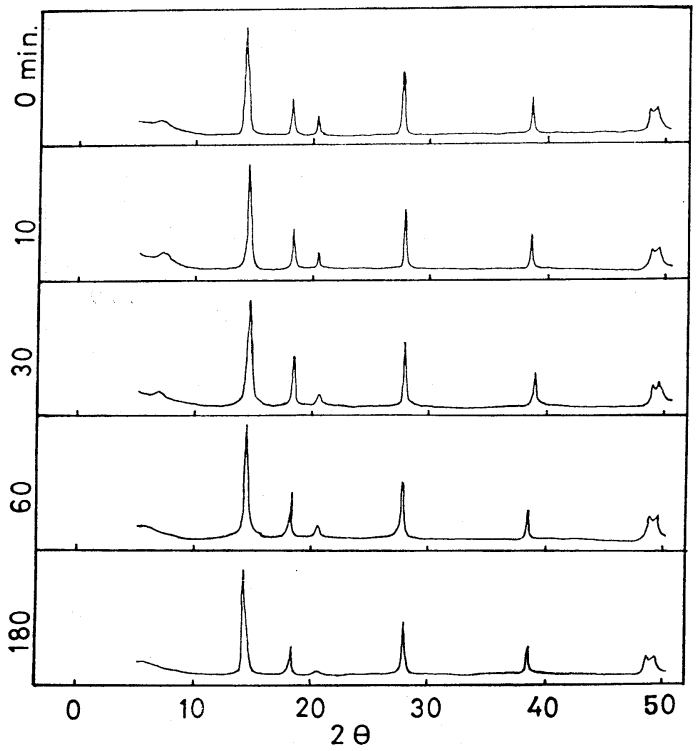

Fig. 13. X-ray diffraction patterns of mixed pigment $(1: 39)$ at different grinding time
1:39 の時と同様, $\mathrm{A}$ の $2 \theta=21^{\circ}$ 付近のピークは 180 分 の摩砕後には，くずれていることが認められた。な抗こ の混合比の場合には, $\alpha-\mathrm{CuPc}$ のピークは未摩砝の場合 に扮いても医とんどみられなかった。以上のことはまた 電子顕微鏡写真にも良く表われている。図-17 は, 未摩 砕と 180 分摩砕後の電子顕微鏡写真の結果である。単独 摩砕の時のように顔料粒子は, 摩砕により微細化される ことが分かる。すなわち $\alpha-\mathrm{CuPc}$ の混合比が極端に小 さい混合比 $1: 79$ の混合摩砕に特いては, $1: 39$ の場合 と同様 $\alpha$-CuPc は潤滑作用を示さないことが明らかで ある。図-18 はA 単独 $\alpha-\mathrm{CuPc}$ 単独执よび混合比 1： 3，1:15，1:39，そして 1:79 の摩砕時間による比表 面積変化をまとめたものである。粉砕時間 180 分に抹い て $1: 3$, 洛よび $1: 15$ はA単独の比表面積よりも大き

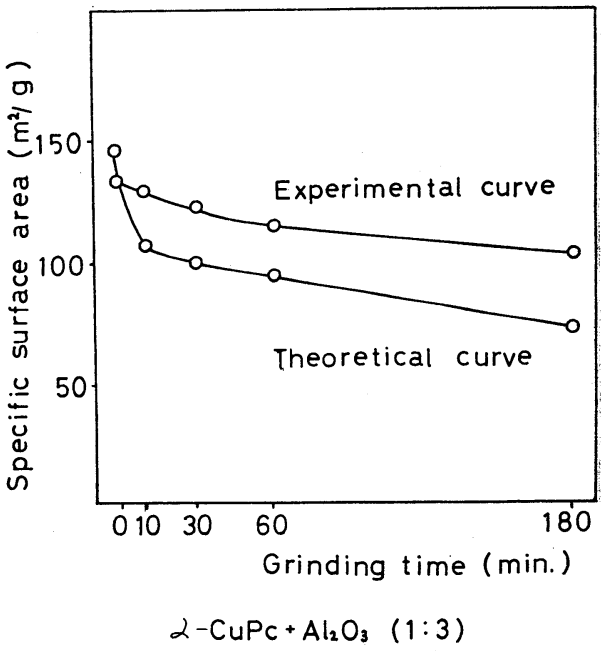

Fig. 15. Change of the specific surface areas of mixed pigment (1:79) with grinding
A

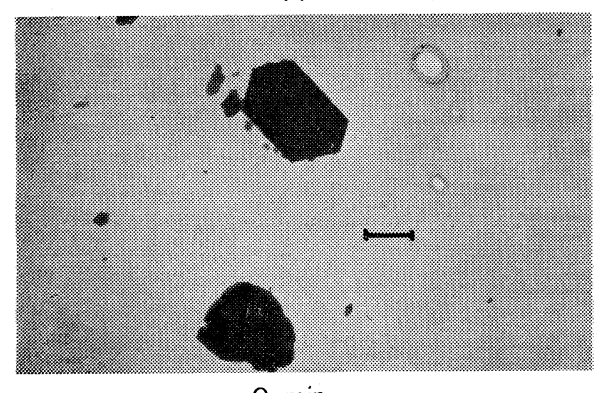

$0 \mathrm{~min}$.
$\alpha-\mathrm{CuPc}+\mathrm{Al}_{2} \mathrm{O}_{3}(1: 39)$

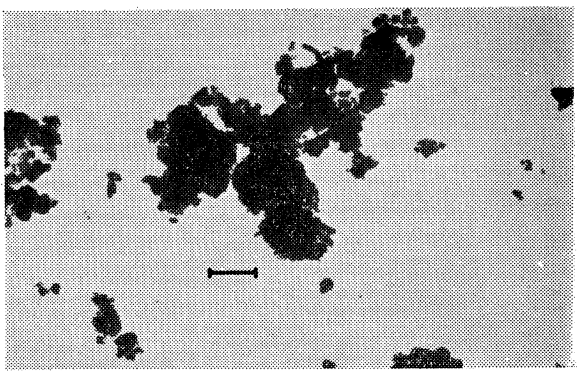

$180 \mathrm{~min}$.

Fig. 14. Electronmicrographs of $(1: 39)$ mixed pigment $(\alpha$-CuPc $+A)$. The linear dimension on electronmicrograph represents one micron length
A. original
B. ground for $180 \mathrm{~min}$ 

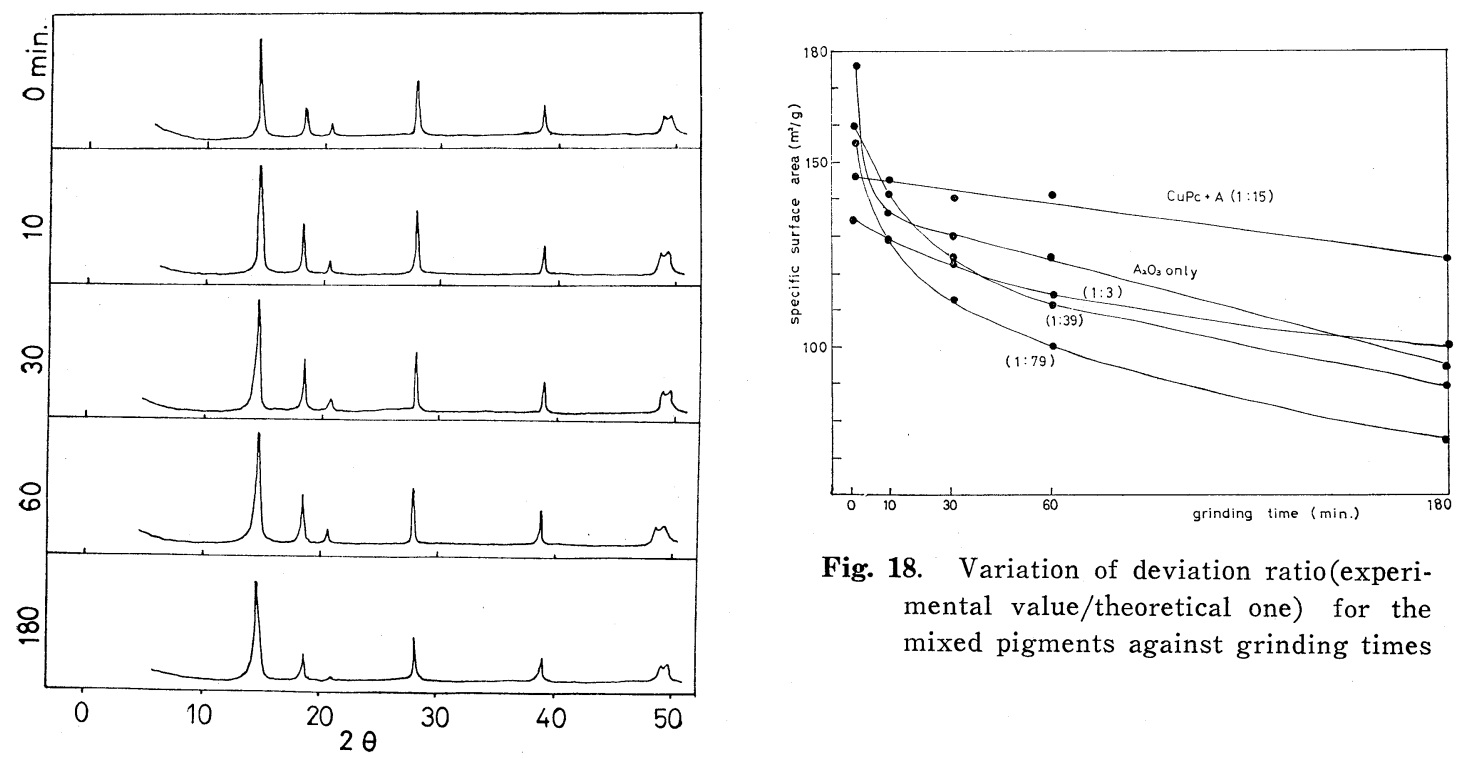

Fig. 18. Variation of deviation ratio(experimental value/theoretical one) for the mixed pigments against grinding times

Fig. 16. $X$-ray diffraction patterns of mixed pigment $(1: 79)$ at different grinding time

$$
\alpha-\mathrm{CuPc}+\mathrm{Al}_{2} \mathrm{O}_{3}(1: 79)
$$

A

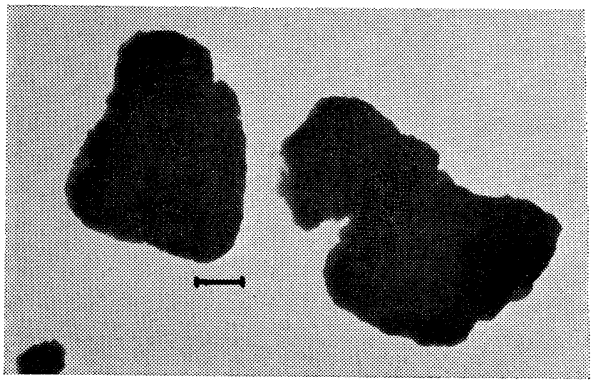

0 min.
B

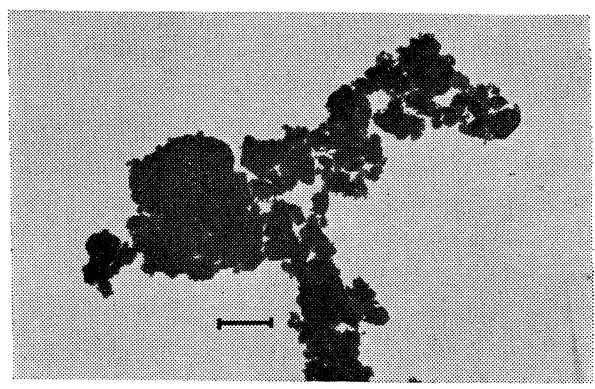

$180 \mathrm{~min}$.

Fig. 17. Electronmicrographs of $(1: 79)$ mixed pigment $(\alpha-\mathrm{CuPc}+\mathrm{A})$. The linear dimension on electronmicrograph represents one micron
A. original
B. ground for $180 \mathrm{~min}$

くまた $1: 39$ 特よび $1: 79$ では，それよりる小さい 値となっている。図-19 は, 各混合顔料の実験料の実験 値の理論值からの “ずれ”の比（理論值/実験值）を摩 确時間に対してプロットしたものである。“ずれ”の比 が 1.0 の所が理論值と実験值の一致する所である。すな わち“ずれ”の比が 1.0 よりも上沉るる值では， $\alpha-\mathrm{CuPc}$ の潤滑作用がみられる部分で，また，1.0 よりも下にな った所では， $\alpha-\mathrm{CuPc}$ の潤滑作用がないるのと考えられ る。そこで $\alpha-\mathrm{CuPc}$ の潤滑作用は, 混合顔料中 $\alpha-\mathrm{CuPc}$ がどのくらいの比率を占める所まで存在するかを示すの が図-20である。図-20 は，180 分摩哗に括ける “ずれ”
の比を混合顔料中に占める $\alpha-\mathrm{CuPc}$ の含有量でプロッ トしたものである。これより $\alpha-\mathrm{CuPc}$ の潤滑作用の拉 よそ限界は $1: 31$ であることがわかる。

以上のことより $\alpha-\operatorname{CuPc}$ がAを十分覆いつくす量有 る場合には，有機顔料である。 $\alpha-\mathrm{CuPc}$ が無機顔料であ るAを包久摩砕の際に， $\alpha-\mathrm{CuPc}$ が一種の潤滑剤の働き をし，Aの摩砝を抑觉るるのと考兄られる。

な技実験に協力された小野恵子・大塚栄一・橋本友男 の諸氏に感謝致します。 


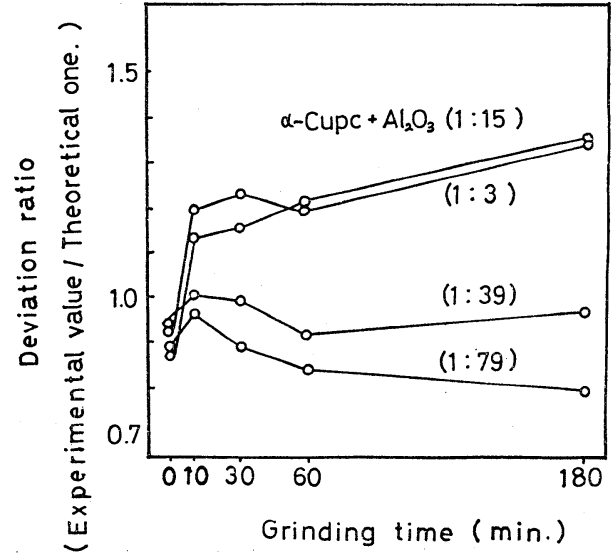

Fig. 19. The specific surface area of pigments mixture with grinding time

5）橋詰源蔵・網田佳代子 : 工化誌, 71, No. 9, 1380 (1968)

6) K. Meguro, I. Koga : farbe \& lack, 79, 503 (1973)

7）久保輝一郎 :「メカノケミストリ一概論」, 東京化 学同人 (1971)

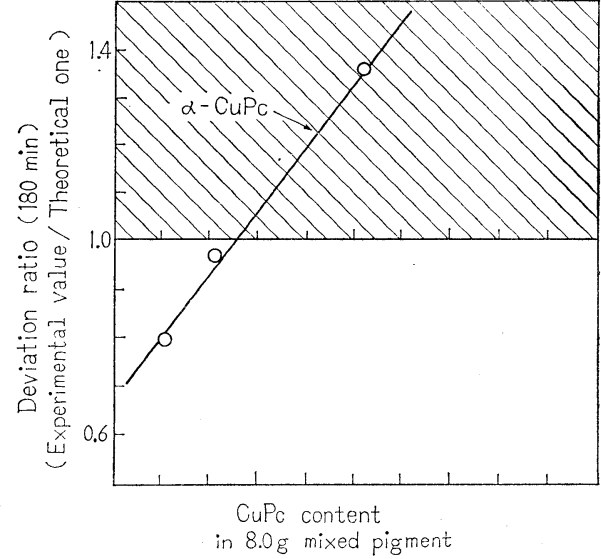

Fig. 20. The deviation ratio it $180 \mathrm{~min}$ grinding against $\alpha-\mathrm{CuPc}$ content in 8. $0 \mathrm{~g}$ mixed pigment

参考文献

1) V. T. Crow1: J. Oil Chem. Assoc., 50, 1023 (1967)

2）山下雄蔵・森田 収：色材，42，400（1969）

3) H. Takahashi, K. Tsutsumi : Bull. Chem. Soc. Japan, 40, 7 (1967)

4) 白崎高保 - 落合康額 - 村中健太郎 : 工化誌, 71, No. 9, 1363 (1968) 